\title{
Myeloid derived suppressor cells - a new therapeutic target in the treatment of cancer
}

\author{
Robert Wesolowski ${ }^{1 \dagger}$, Joseph Markowitz ${ }^{2 \dagger}$ and William E Carson $\mathrm{II}^{3^{*}}$
}

\begin{abstract}
Myeloid Derived Suppressor Cells (MDSC) are a heterogeneous population of immature myeloid cells that are increased in states of cancer, inflammation and infection. In malignant states, MDSC are induced by tumor secreted growth factors. MDSC play an important part in suppression of host immune responses through several mechanisms such as production of arginase 1, release of reactive oxygen species and nitric oxide and secretion of immune-suppressive cytokines. This leads to a permissive immune environment necessary for the growth of malignant cells. MDSC may also contribute to angiogenesis and tumor invasion. This review focuses on currently available strategies to inhibit MDSC in the treatment of cancer.
\end{abstract}

Keywords: Myeloid derived suppressor cells, Immunotherapy, Tumor immunology, Cancer vaccines

\section{Introduction}

Myeloid derived suppressor cells (MDSC) are a population of early myeloid cells that are expanded in various disease states including cancer and are capable of suppressing the immune response [1,2]. In mice, MDSC express myeloid markers ( $\mathrm{Gr} 1$ or $\mathrm{CD} 11 \mathrm{~b})$. In humans, the Gr1 antigen is absent. Human MDSC express myeloid

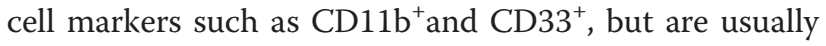
negative for HLA-DR and lineage specific antigens (Lin) such as CD3, CD19 and CD57. Monocytic MDSC are usually characterized by HLA-DR-, CD11b+, CD33+ and $\mathrm{CD}_{14}{ }^{+}$phenotype in humans $\left(\mathrm{CD} 11 \mathrm{~b}+\mathrm{Ly} 6 \mathrm{G}^{-} / \mathrm{Ly} 6 \mathrm{C}^{+}\right.$in mice) whereas mature monocytes express HLA-DR. Granulocytic MDSC are usually characterized by HLADR-, CD11b+, CD33+, CD15+ phenotype in humans $\left(\mathrm{CD} 11 \mathrm{~b}+\mathrm{Ly}_{6 \mathrm{G}} \mathrm{L}^{+} \mathrm{Ly} 6 \mathrm{C}^{\text {low }}\right.$ in mice). The immune cells with these phenotypes have been shown to possess immunosuppressive properties [3-5]. The prevalence of MDSC immunophenotypes vary depending on the disease being studied [2,3]. An extensive discussion of MDSC phenotypic and functional heterogeneity is outside of the scope of this article and recent excellent reviews on this topic exist [1-3].

\footnotetext{
* Correspondence: William.Carson@osumc.edu

${ }^{\dagger}$ Equal contributors

${ }^{3}$ The Ohio State University Comprehensie Cancer Center, N911 Doan Hall, 410 West 10th Avenue, Columbus, OH 43210, USA

Full list of author information is available at the end of the article
}

MDSC can be generated in the bone marrow in response to cancer derived factors such as granulocyte colony stimulating factor (G-CSF), IL-6, granulocyte monocyte colony stimulating factor (GM-CSF), IL-1 $\beta$, prostaglandin E2 (PGE2), tumor necrosis factor $\alpha$ (TNF $\alpha$ ) and vascular endothelial growth factor (VEGF) and are recruited to the tumor site by CCL2, CXCL12, and CXCL5 [6]. Additional signals stimulate MDSC to acquire immunosuppressive properties which are mediated through members of the signal transducer and activator of transcription (STAT1, STAT3, STAT6) and nuclear factor kappa-light-chainenhancer of activated B cells (NF- $\mathrm{kB}$ ) transcription factors [1]. Activated MDSC produce arginase 1 (ARG1), inducible nitric oxide synthase (NOS2), IDO (indoleamine 2,3dioxygenase), NADPH oxidase and immunosuppressive cytokines that have the potential to inhibit cytotoxic $\mathrm{T}$ lymphocytes (CTLs), dendritic cells (DC), and natural killer (NK) cells as well as expand $\mathrm{CD}^{+}{ }^{+} \mathrm{CD} 25^{+} \mathrm{FoxP}^{+}$ regulatory $\mathrm{T}$ cells (Tregs). This leads to an immunologically permissive tumor microenvironment $[7,8]$. Peripheral blood MDSC levels correlate with a higher tumor burden and a worse prognosis [9-11]. MDSC may impair the efficacy of cancer vaccines via direct effects on T cell activation and antigen presentation by DC [12]. Inhibition of MDSC in murine models may enhance anti-tumor immunity by increasing responsiveness to interferon stimulation [13]. Inhibition or depletion of MDSC enhances the activity of cancer vaccines in animal models (Table 1).
C Biomed Central

(c) 2013 Wesolowski et al.; licensee BioMed Central Ltd. This is an Open Access article distributed under the terms of the Creative Commons Attribution License (http://creativecommons.org/licenses/by/2.0), which permits unrestricted use, distribution, and reproduction in any medium, provided the original work is properly cited. 
Table 1 Murine cancer vaccine studies that utilized MDSC inhibitors

\begin{tabular}{|c|c|c|c|}
\hline MDSC Inhibition Strategy & Tumor model & Vaccine & Effect of MDSC Modulation \\
\hline \multirow[t]{2}{*}{$\overline{\text { ATRA [14] }}$} & (a) C3 fibrosarcoma in C57BL/6 mice & (a) $H-2 D^{b}$-restricted epitope of the HPV-16 E7 & $\begin{array}{l}\text { (a) Decreased tumor size by } \sim 3 \text { fold at } 35 \text { days; } \\
\text { enhanced } C D 8^{+} \text {response }\end{array}$ \\
\hline & $\begin{array}{l}\text { (b) 3-methylcholanthrene-induced sarcoma } \\
\text { containing mutant p53 gene in BALB/c mice }\end{array}$ & (b) Wild type p53 DC vaccine & $\begin{array}{l}\text { (b) Decreased tumor size by } \sim 5 \text { fold; enhanced } \\
\text { CD8+ responses }\end{array}$ \\
\hline Gemcitabine [15] & $\begin{array}{l}\text { Pancreas adenocarcinoma (Panc02) expressing } \\
\text { murine survivin in C57BL/6 mice }\end{array}$ & $\begin{array}{l}\text { Modified Vaccinia Ankara virus (MVA) expressing } \\
\text { murine survivin protein }\end{array}$ & $\begin{array}{l}50 \% \text { survival vs. } 0 \% \text { in control mice at } 50 \text { days; } \\
\text { enhanced } \mathrm{CD}^{+} \text {responses }\end{array}$ \\
\hline ATRA + anti-CD25 antibody [16] & $\begin{array}{l}\text { Tumor bearing } \mid \mathrm{L}-1 \mathrm{RI} \text { competent or } \mid \mathrm{L}-1 \mathrm{RI} \\
\text { deficient mice }\end{array}$ & $\begin{array}{l}\text { CDNA IL-1 a attenuated S. typhimurium and/or IL-1 } \\
\text { competent or IL-1 deficient fibrosarcoma cell lysates }\end{array}$ & $\begin{array}{l}\text { Decreased MDSC and Treg levels; significantly } \\
\text { enhanced survival of IL-1 RI competent mice }\end{array}$ \\
\hline \multirow[t]{2}{*}{$\begin{array}{l}\text { Nitroaspirin derivative } \\
(\text { NCX-4016) [17] }\end{array}$} & $\begin{array}{l}\text { (a) CT26 colon carcinoma in C57BL/6 and } \\
\text { BALB/c mice }\end{array}$ & $\begin{array}{l}\text { Plasmid DNA vaccine encoding extracellular and } \\
\text { trans-membrane domains of p185 peptide }\end{array}$ & (a) $20 \%$ cure rate at 120 days \\
\hline & $\begin{array}{l}\text { (b) Her-2/neu }+(\mathrm{p} 185) \mathrm{N} 2 \mathrm{C} \text { breast carcinoma } \\
\text { in C57BL/6 and BALB/C mice }\end{array}$ & & (b) $56 \%$ cure rate at 120 days \\
\hline CDDO-Me (Triterpenoid) [18] & EL-4 thymoma in C57BL/6 & DC transduced with murine survivin & $\begin{array}{l}\text { Decreased tumor size by } 2 \text { fold; enhanced } \\
\text { antigen specific immune response }\end{array}$ \\
\hline \multirow[t]{2}{*}{$\begin{array}{l}\text { IL-13-PE (cytotoxin composed } \\
\text { of IL-13 and Pseudomonas } \\
\text { exotoxin) [19] }\end{array}$} & (a) $4 \mathrm{~T} 1$ breast carcinoma in BALB/C mice & DNA vaccine encoding a2 chain of IL-13R & $\begin{array}{l}\text { Decreased tumor size by } 5 \text { fold; decreased MDSC } \\
\text { and Treg levels; enhanced T cell responses; } \\
\text { enhanced survival by } 35 \text { days. }\end{array}$ \\
\hline & (b) MCA304 sarcoma in C57BL/6 mice & & \\
\hline Sunitinib [20] & MO5 (B16.OVA: H-2 ${ }^{b}$ ) melanoma on C57BL/6 mice & $\begin{array}{l}\text { IL-12 transfected DC pulsed with OVA I and II } \\
\text { peptides. }\end{array}$ & $\begin{array}{l}\text { Loss of tumor associated MDSC and Tregs; } \\
\text { enhanced } C D 8^{+} T \text { cell responses }\end{array}$ \\
\hline \multirow[t]{3}{*}{ Gemcitabine [21] } & $\begin{array}{l}\text { Her-2/neu + SK-BR-3 breast carcinoma or } \\
\text { mHER2/CT26 (colon carcinoma transfected } \\
\text { with murine Her-2/neu) in BALB/c mice }\end{array}$ & (a) AdhHM & (a) No anti-tumor effect of AdhHM alone \\
\hline & & (b) AdhHM + anti- GITR antibody & $\begin{array}{l}\text { (b) Decreased tumor size by }>5 \text { fold; }(p<0.005) \text {; } C D 8^{+} \\
\text {cell dependent rejection of syngeneic tumor cells }\end{array}$ \\
\hline & & (c) AdhHM + a galactosylceramide loaded DCs & (c) Decreased tumor size by $>5$ fold \\
\hline Cisplatin [22] & $\begin{array}{l}\text { TC-1 lung carcinoma expressing E7 protein in } \\
\text { C57BL/6 mice }\end{array}$ & E7 DNA vaccine & $\begin{array}{l}\text { Enhanced tumor lysis mediated by E7 specific } \mathrm{CD}^{+} \\
\text {cells; reduced tumor volume }\end{array}$ \\
\hline Zoledronic Acid [23] & $\begin{array}{l}\text { Transgenic Balb T-Neu mice (express activated } \\
\text { rat } c \text {-erbB-2/neu transgene) }\end{array}$ & $\begin{array}{l}\text { Plasmid DNA encoding portion of the rat } \\
\text { p185/Her-2 gene }\end{array}$ & Delayed tumor onset and reduced in tumor size \\
\hline
\end{tabular}

Abbreviations: ATRA - All-Trans Retinoic Acid, AdhHM - Adenoviral vector expressing xenogenic human Her-2/neu, DC - Dendritic Cell, GITR - Glucocorticoid Induced Tumor Necrosis Factor Receptor Family- Related Receptor. 
MDSC inhibition could be a useful adjunct to immune therapies in man and can be placed into four categories; 1) Deactivation of MDSC; 2) Differentiation of MDSC into mature cells; 3) Inhibition of myeloid cell development into MDSC; and 4) Depletion of MDSC (Figure 1). This review was undertaken to help researchers and clinicians become familiar with the many agents that can modulate MDSC function. Asterisk $\left({ }^{*}\right)$ was placed in Figure 1 next to the agents that are already undergoing clinical investigation as potential MDSC inhibitors in humans.

\section{Review}

Strategies for MDSC deactivation

Phosphodiesterase- 5 inhibitors deactivate MDSC by interfering with arginase 1 and nitric oxide synthase expression

Phosphodiesterase-5 (PDE-5) inhibitors such as sildenafil and tadalafil inhibit the degradation of cyclic guanosine monophosphate (cGMP) leading to reduction in ARG1 and NOS2 expression [24]. It is not entirely clear how this occurs but it has been proposed that high cGMP levels could interfere with expression of IL-4R $\alpha$ on

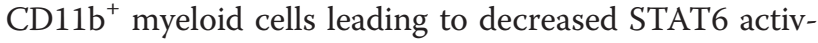
ity and reduced levels of NOS2 and ARG1 [24]. ARG1 mediated depletion of L-arginine from the tumor microenvironment may be one of the mechanisms of MDSC induced $\mathrm{T}$ cell suppression secondary to decreased expression of the $\zeta$ subunit of CD3 [25]. MDSC also decrease the concentration of cysteine and tryptophan required for $\mathrm{T}$ cell activity [26]. However, some groups argue that IL4R $\alpha$ is not involved in this process [27]. Proposed alternative mechanisms by which PDE-5 inhibitors function include destabilizing NOS2 mRNA, and decreasing cytosolic calcium concentration thereby reducing calcium-dependent protein kinase $C$ signal transduction [24]. Treatment of mice with a PDE-5 inhibitor reduces the ability of MDSC to inhibit $\mathrm{CD}^{+} \mathrm{T}$ cells and leads to delayed tumor growth in mice inoculated with CT26WT colon carcinoma cells (a sign that $\mathrm{T}$ cellmediated immunity might have been restored). The expansion of $\mathrm{T}$ cells within the peripheral blood mononuclear cell (PBMC) fraction isolated from patients with head and neck cancer and multiple myeloma and stimulated with anti-CD3/CD28 antibody-coated beads was enhanced following in-vitro treatment of PBMC with sildenafil [24].

Several clinical studies with PDE-5 inhibitors have been initiated. A phase II study in multiple myeloma is testing whether tadalafil can improve the response to lenalidomide and dexamethasone (NCT01374217 on www.clinicaltrials.gov). Other studies are testing whether neo-adjuvant tadalafil treatment in patients with oropharyngeal carcinoma can improve the infiltration of $\mathrm{CD}^{+}$and $\mathrm{CD}^{+}$cells into tumors (NCT00843635). A randomized trial of systemic chemotherapy with or without sildenafil in patients with non-small cell lung carcinoma (NCT00752115) has completed enrollment, while a phase I trial in pancreatic cancer is testing tadalafil and a telomerase vaccine alongside with gemcitabine chemotherapy followed by low dose gemcitabine and radiation therapy (NCT01342224).

\section{Strategies of MDSC Inhibition Under Investigation}

\begin{tabular}{|c|c|}
\hline Deactivation of MDSC & $\begin{array}{l}\text { Differentiation of MDSC } \\
\text { into mature cells }\end{array}$ \\
\hline $\begin{array}{l}\text { NO Inhibitors } \\
\text {-PDE-5 inhibitors* } \\
\text { - NO-aspirins* } \\
\text {-L-NAME } \\
\text { Arginase Inhibitors } \\
\text {-PDE-5 Inhibitors* } \\
\text {-COX2 inhibitors } \\
\text {-NOHA } \\
\text {-L-NAME } \\
\text { ROS Inhibitors } \\
\text {-Synthetic Triterpenoids } \\
\text { MDSC Migration } \\
\text { Inhibitors } \\
\text {-Anti-glycan antibodies } \\
\text {-CSF-1R inhibitors* } \\
\text { Others } \\
\text {-Histamine inhibitors } \\
\text {-Anti-IL-17 Antibodies }\end{array}$ & $\begin{array}{l}\frac{\text { Vitamins }}{\cdot \text {-ATRA* }} \\
\cdot \text {-Vitamin A } \\
\cdot \text {-Vitamin D3* } \\
\frac{\text { Cytokines }}{\cdot \text {-L-12 }} \\
\frac{\text { Others: }}{\cdot \text { CpG }}\end{array}$ \\
\hline
\end{tabular}

\begin{tabular}{|l|}
\hline $\begin{array}{c}\text { Blocking Development } \\
\text { of MDSC }\end{array}$ \\
\hline \hline Bisphosphonates \\
-Zoledronic Acid* \\
Modulators of Cell \\
\hline Signaling \\
-JAK2/STAT3 inhibitors* \\
-Multi-Kinase Inhibitors* \\
-VEGF Inhibitors* \\
\\
\end{tabular}

\begin{tabular}{|l|}
\hline \multicolumn{1}{|c|}{ Depletion of MDSC } \\
\hline \hline Cytotoxic Agents \\
- Gemcitabine \\
- Cisplatin \\
-Paclitaxel \\
-5-Fluorouracil \\
HSP 90 Inhibitors \\
-17-DMAG \\
-Others \\
-IL-6R blockers \\
-Antibody Drug \\
Conjugates (ex IL-13-PE)
\end{tabular}

Figure 1 Graphical representation of MDSC inhibition strategies. (Abbreviations: NO - Nitric Oxide; PDE-5 - Phosphodiesterase 5; NO-Aspirin Nitro-aspirin; L-Name - N(G)-Nitro-L-Arginine Methyl Ester; COX2 - Cyclooxygenase 2; CSF-1R - Colony Stimulating Factor Receptor 1; ATRA - All Trans Retinoic Acid; CpG - Deoxycytosine-Deoxyguanine Dinucleotide; JAK2 - Janus-Activated Kinase-2; STAT3 - Signal Transducer and Activator of Transcription 3; VEGF - Vascular Endothelial Growth Factor; 17-DMAG - 17-Dimethylaminoethylamino-17-Demethoxygeldanamycin; IL-6R - IL-6 Receptor); ${ }^{*}$ - Agents that are presently under clinical investigation as MDSC inhibitors. 


\section{Nitro-aspirin (NO-aspirin) interferes with MDSC nitric oxide metabolism}

Decreased $\mathrm{T}$ cell responsiveness in the presence of MDSC may be a direct result of nitric oxide production by MDSC leading to increased nitration of the $\mathrm{T}$ cell receptor, CCL2 or STAT1 [13,28,29]. NO-aspirins suppress the production of reactive oxygen species (ROS) and provide feedback inhibition of NOS2 [30]. A potent NOaspirin, AT-38 (([3-(aminocarbonyl)furoxan-4-yl]methyl salicylate) inhibits inducible NOS via various mechanisms and leads to the reversal of MDSC induced inhibition of T-cell responses in-vitro by reducing CCL2 chemokine nitration [29]. Treatment of C26 colon carcinoma-bearing mice with a nitro-aspirin, NCX-4016 (2-(acetyloxy)benzoic acid 3-(nitrooxymethyl)phenyl ester) improved $\mathrm{T}$ cell proliferation, decreased numbers of MDSC within the tumor, and retarded tumor growth compared to control animals [17]. De Santo et al. challenged mice with a DNA vaccine encoding the endogenous retro-viral envelope glycoprotein gp70 (gp70env) and established CT26 tumors that express gp70env. The mice were treated with $\mathrm{NO}$-aspirin on days 1-18 following tumor challenge, which resulted in significantly longer survival of the vaccinated animals. At 120 days, 20\% of animals treated with NCX-4016 and the vaccine did not develop tumors, whereas all mice that received either NCX-4016 or the vaccine alone developed tumors [17]. NCX-4016 therapy is presently under investigation in a phase I clinical trial for prevention of colorectal cancer in patients at high risk of developing this malignancy (NCT00331786).

\section{Synthetic triterpenoids deactivate MDSC by reducing reactive oxygen species (ROS)}

Bardoxolone methyl (CDDO-Me), a synthetic triterpenoid, is a methyl ester of 2-cyano-3,12-dioxooleana-1,9 (11)-dien-28-oic acid and is a potent activator of the nuclear factor-erythroid 2-related factor 2 (NFR2) transcription factor. NFR2 leads to up-regulation of antioxidant genes, including NADPH: quinone oxidoreductase 1 (NQO1), and thioredoxin [31]. At higher concentrations (1-5 $\mu \mathrm{M})$, CDDO-Me can inhibit STAT3, reducing the expansion of MDSC [1,32]. CDDO-Me treatment of $\mathrm{Gr}^{+} / \mathrm{CD} 11 \mathrm{~b}^{+}$splenocytes isolated from mice bearing the EL-4 thymoma caused up-regulation of the antioxidant enzyme NQO1, decreased concentrations of ROS, and led to reduced levels of nitro-tyrosine residues inside MDSC. CDDO-Me treatment of tumorbearing mice led to decreased MDSC production of ROS, improvement in $\mathrm{T}$ cell function and reduced tumor growth. In an allogeneic mixed leukocyte reaction, MDSC-mediated inhibition of $\mathrm{T}$ cells from patients with renal cell carcinoma was abrogated by CDDO-Me at a concentration of 200-300 nM, which is achievable in vivo. CDDO-Me treatment of mice bearing EL-4 tumors greatly enhanced the anti-tumor effects of a vaccine consisting of survivin-transduced $\mathrm{DC}$ and this was associated with a robust $\mathrm{T}$ cell response to re-stimulation with a survivin-derived peptide [18]. CDDO-Me treatment of pancreatic cancer patients receiving gemcitabine in a phase I clinical trial led to significantly increased $\mathrm{T}$ cell responses to tetanus toxoid and phytohemagglutinin (Clinical Trial No. RTA 402-C-0702).

\section{Cyclooxygenase 2 (COX2) inhibitors reduce MDSC} suppressive function by decreasing expression of Arginase 1 MDSC have increased expression of the Prostaglandin E (PGE) receptor. Treatment of tumor-bearing mice with a COX-2 inhibitor led to an approximate $50 \%$ reduction in tumor growth rate and decreased levels of $\mathrm{Gr} 1^{+} / \mathrm{CD} 11 \mathrm{~b}^{+}$ cells. These results were confirmed in PGE2 receptor knockout mice [33]. Rodriguez et al. showed that PGE2 produced by 3LL lung carcinoma cells was able to induce ARG1 expression in tumor-associated MDSC [34]. Treatment of 3LL tumor-bearing mice with the COX-2 inhibitor sc-58125 led to complete blockade of ARG1 expression in the tumor and a statistically significant decrease in tumor volume (compared to untreated tumor baring animals), an effect that was not observed in immune-deficient mice. A widely used COX-2 inhibitor, celecoxib, was administered to mice that had been treated with 1,2-dimethylhydrazine $\mathrm{diHCl}$ to stimulate the development of colon cancer. Celecoxib use was associated with lower levels of $\mathrm{Gr}^{+} / \mathrm{CD} 11 \mathrm{~b}^{+}$myeloid cells and higher numbers of tumor infiltrating lymphocytes [35]. COX2 inhibitors may therefore have more than one mechanism of suppressing MDSC, namely they can block their activation and also reduce their numbers [36].

\section{Other arginase inhibitors}

One of the most potent physiologic inhibitors of ARG1 activity is N-hydroxy-L-Arginine (NOHA), an oxidized form of arginine that is an intermediate in the enzymatic conversion of arginine to citruline and nitric oxide by NOS2 [37]. This compound has been used as an ARG inhibitor in animal and in vitro studies where inhibition of MDSC function was desired. For example, in experiments involving the A20 B-cell lymphoma line, use of NOHA effectively inhibited MDSC mediated expansion of Tregs and eliminated tumor induced immune tolerance [38].

N(G)-Nitro-L-Arginine Methyl Ester (L-NAME) is another compound that has been shown to inhibit Arg 1 activity [39]. In addition, L-NAME is a transcriptional downregulator of NOS which leads to reduced production of nitric oxide [40]. L-NAME was shown to 
decrease immunosuppressive MDSC activity in C57BL/6 mice bearing the C26GM colon carcinoma and RMA T lymphoma cells leading to slower tumor growth and improved tumor specific immune responses in the treated animals [41]. Regamonti and colleagues were able to demonstrate that treatment of C57BL/6 mice implanted with TRAMP-C1 prostate cancer cells with L-NAME resulted in reduction in the immunosuppressive action of $\mathrm{CD} 1 \mathrm{~b}^{+}$myeloid cells (including inhibition of Arg1 activity) in the spleen and within the tumor. The treatment also improved survival of the treated animals (50\% of tumor bearing mice were alive at the time when all vehicle treated mice had died from tumor overgrowth at about 36 days post implantation). However, the agent did not inhibit tumor progression or break the tumor specific tolerance of a transgenic murine model that spontaneously developed prostate adenocarcinoma. In-vitro assays showed an inability of activated CD8+ T-cells derived from the spleens of L-NAME treated animals to lyse syngeneic target tumor cells [42].

\section{Anti-glycan antibody inhibits the migration of MDSC}

The Receptor for Advanced Glycation End Products (RAGE) is modified post-translationally by the addition of carboxylated glycans at several amino-acid residues. RAGE is present on the membrane of colon carcinomas, while one of its ligands, S100A8/A9 is expressed on $\mathrm{Gr}^{+} / \mathrm{CD} 11 \mathrm{~b}^{+}$murine MDSC. S100A8/A9 is induced via STAT3 mediated signaling and appears to be involved in upregulation of MDSC in cancer and the differentiation of dendritic cells and macrophages [43]. Interference with S100A8/A9 signaling can result in inhibition of MDSC function leading to decreased tumor growth. This has been demonstrated in experiments involving mice that develop colorectal cancer in response to treatment with azoxymethane (AOM) and exposure to the inflammatory agent dextran sodium sulfate (DSS) (AOM-DSS mice). AOM-DSS mice treated with the anti-glycan mAbGB3.1 demonstrated a $75 \%$ reduction in the formation of colonic tumors and decreased serum levels of NF-kB-induced cytokines such as TNF $\alpha$ and IL-6. This result suggested that RAGE and S100A8/A9 form a feedback loop that could play a role in promoting MDSC recruitment to colon cancers and provides a rationale for the clinical use of anti-glycan antibodies [44]. Sinha et al. have shown that RAGE and other cell surface glycoproteins may be present on MDSC. MDSC expression of S100A8/A9 can therefore complete an autocrine loop that leads to enhanced MDSC accumulation. This RAGE-S100 signaling loop may activate the NF- $\mathrm{B}$ transcription factor, which suggests that NF- $\mathrm{B}$ inhibitors might also be an effective means of blocking MDSC activity [45].

\section{Inhibitors of colony stimulating factors and their receptors block the migration of MDSC}

Colony stimulating factor receptor 1 (CSF-1R) may play a role in recruitment of MDSC to tumor sites and the induction of angiogenesis. BALB/c mice bearing C26GM colon carcinoma tumors that secrete GM-CSF exhibit high levels of MDSC in the spleen and tumor [17]. Treatment of mice bearing Lewis Lung Carcinoma tumors with a small molecule inhibitor of CSF-1R (GW2580: 5-(3-Methoxy-4-((4-methoxybenzyl)oxy)benzyl)pyrimidine-2,4-diamine) inhibited the recruitment of $\mathrm{CD}_{11 \mathrm{~b}}{ }^{\mathrm{G}} \mathrm{Gr} 1^{\mathrm{lo}} \mathrm{Ly} 6 \mathrm{C}^{\mathrm{hi}}$ monocytic MDSC into tumors and reduced the expression of pro-angiogenic and immunosuppressive genes within the tumor microenvironment [46]. $\mathrm{Xu}$ and colleagues demonstrated that tumor irradiation of C57BL/6 mice implanted with syngeneic RM-1 prostate cancer cells led to an increase in CSF1 expression by the tumor cells, which was dependent on activation of ABL-1 tyrosine kinase. This further led to infiltration of the tumors by the tumor associated macrophages (TAM) as well as monocytic and granulocytic MDSC. Blocking CSF-1R with GW2580 or PLX3397 following tumor irradiation resulted in a decrease of myeloid cell infiltration (both TAM and MDSC) in the tumors and spleens and led to a slower tumor growth compared to irradiated animas not treated with CSF-1R inhibitor [47]. Monoclonal antibodies that block the CSF-1R (e.g. IMC-CS4) as well as small molecule inhibitors of CSF-1R (e.g. PLX-3397) are undergoing phase I clinical trials.

\section{Histamine and MDSC}

It has been shown that histamine may stimulate GMCSF and IL-6 production via histamine $\mathrm{H}_{1}$ and histamine $\mathrm{H}_{2}$ receptors on human PBMC in-vitro [48]. However, more recently, in an in-vivo model by Yang et $a l$., it has been shown that a deficiency of histamine directly stimulates the production of $\mathrm{CD} 11 \mathrm{~b}^{+} \mathrm{Ly}_{6 \mathrm{G}}{ }^{+}$ early myeloid cells in murine models of skin and colon carcinogenesis [49]. In the commentary to this article, it was described that histamine is approved as an agent for AML in Europe and Israel and has been found to have anti-tumor effects in melanoma, lymphoma, fibrosarcoma and colon cancer [50]. H2 blockers such as cimetidine appear to induce apoptosis of MDSC through induction of Fas and FasL [51].

\section{Other potential approaches to inhibit MDSC activation}

IL-17 also seems to be important for recruiting of MDSC to tumor sites in murine models [52]. In experiments involving tumor-bearing mice that were deficient in IL-17R and IFN $\gamma R$, tumor development was inhibited and this was associated with increased cytotoxic $\mathrm{T}$ cell infiltration of tumors and lower MDSC levels. Also, 
treatment of tumor-bearing wild type mice with neutralizing anti-IL-17 antibody led to decreased tumor growth. Conversely, IL-17 treatment promoted tumor growth and MDSC infiltration of tumors [52].

\section{MDSC differentiating agents \\ All-trans retinoic acid}

All-trans retinoic acid (ATRA) is a metabolite of vitamin A with agonistic activity towards nuclear receptors that are retinoid-activated transcriptional regulators (RAR $\alpha$, $\operatorname{RAR} \beta$, etc.) [53]. These factors activate target genes that lead to maturation of early myeloid cells into their fully differentiated (and hence less-immunosuppressive) forms [54]. MDSC isolated from the peripheral blood of patients with advanced renal cell carcinoma express RAR $\alpha$ and RAR $\gamma$ nuclear receptors. Treatment of MDSC with ATRA led to increased MDSC expression of differentiation markers such as HLA-DR [55]. Adoptive transfer experiments in tumor-bearing animals showed that ATRA can lead to differentiation of MDSC into DC, granulocytes and monocytes with concomitant improvement of CTLmediated immune responses [14]. ATRA administration improves vaccine therapy in several murine models. Mice treated with a vaccine targeting the $\mathrm{H}-2 \mathrm{D}^{\mathrm{b}}$-restricted epitope of the Human Papilloma Virus 16 (HPV-16) E7 protein after C3 fibrosarcoma tumor implantation and exposed to ATRA displayed a 3 fold decrease in tumor growth and improved splenocyte IFN $\gamma$ production. Similarly, BALB/c mice inoculated with immunogenic 3-methylcholantrene-induced sarcomas expressing a mutant p53 gene, and treated with wild type p53 primed DC had 5 fold smaller tumors after ATRA treatment. Only $\mathrm{T}$ cells isolated from the spleens of ATRA treated, immunized mice demonstrated a significant antigen-specific immune response 4 weeks after tumor inoculation [14].

In one study, treatment of 18 renal cell carcinoma patients with ATRA for 7 days led to a significant reduction in peripheral blood MDSC. Patients who achieved high ATRA plasma concentrations had a decline in peripheral blood MDSC to levels seen in healthy control subjects. This was associated with an improvement in the plasmacytoid to myeloid DC ratio, higher IFN $\gamma$ and IL-2 plasma levels, and an increased type 1 to type 2 T-helper cell ratio (Th1/Th2) [56]. Two clinical trials that employ ATRA to modulate MDSC are currently in process. A phase II trial in patients with lung adenocarcinoma resistant to chemotherapy is testing an allogeneic tumor based-cell vaccine and the cytotoxic agent cyclophosphamide in combination with ATRA (NCT00601796). And a randomized phase II trial is testing whether ATRA can enhance the efficacy of chemotherapy combined with a vaccine consisting of DC transduced with a p53 expressing adenoviral vector in patients with extensive stage small cell lung cancer (NCT00618891).

\section{Vitamins}

Vitamins such as Vitamin D3 or Vitamin A may also enhance maturation of myeloid cells. In-vitro studies show that these vitamins decrease levels of immature myeloid cells by inducing their maturation and lead to improved anti-tumor activity in the context of immunotherapeutic interventions [1,57]. A study with 25-hydroxy-vitamin D was conducted in patients with squamous cell carcinoma of head and neck. Patients receiving the highest dose (60 $\mu \mathrm{g} /$ day) had significantly increased expression of HLA-DR on myeloid cells and increased blood levels of IL-12 and IFN $\gamma$ [58].

\section{Other differentiating agents}

DNA fragments that contain a high frequency of unmethylated deoxycytosine-deoxyguanine dinucleotide (CpG) motifs (common in bacterial and viral DNA) can stimulate immune cells via Toll-like receptor 9 (TLR9). TLR9 is expressed on DC, B cells, monocytes and NK cells. Stimulation of TLR9 activates the immune response through increased production of IL-12 and type I interferons [59]. Treatment of mice with TLR9 ligand agonists such as $\mathrm{CpG}$ oligodeoxynucleotides (ODN) decreased the prevalence of the $\mathrm{LY}^{\mathrm{G}}{ }^{\mathrm{hi}}$ MDSC subset. CpG ODN promoted the increased production of IFN $\alpha$ by cytoplasmoid DC, which is thought to mediate maturation of MDSC. Administration of IFN $\alpha$ alone can abrogate MDSC mediated T cell inhibition [60].

Macrophage-mediated IL-12 production can be inhibited by MDSCs in chronic inflammation via activation of a TLR4 signaling pathway [61]. In experiments with a spontaneously metastasizing 4T1 mouse mammary carcinoma cells, MDSC were found to suppress Th1 immunity. MDSC interacted with macrophages leading to decreased production of IL-12 and increased production of IL-10. The result was the predominance of a Th2 immune response favorable to cancer growth [61]. In a murine model of breast cancer, mice treated with IL-12 exhibited differentiation of MDSC at tumor sites, increased overall survival, decreased lung metastasis, and reduced levels of mRNA encoding NO2 and IFN $\gamma$ [62]. In another study, lymphodepleted mice bearing subcutaneous tumors were treated with syngeneic T cells that were co-transduced with an anti-VEGFR-2 (Vascular Endothelial Growth Factor Receptor 2) chimeric antigen receptor (CAR) and constitutively expressed single-chain murine IL-12. Administration of these $\mathrm{T}$ cells to the tumor bearing mice led to retardation of tumor growth and inhibition of systemic and

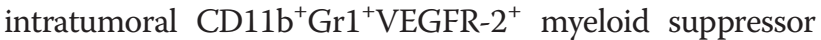
cells [63]. However, it was shown that the anti-tumor effects of IL-12 were not dependent upon direct binding of 
IL-12 to receptors on lymphocytes or NK cells. Instead, IL-12 indirectly enhanced the activity of adoptively transferred $\mathrm{CD}^{+} \mathrm{T}$ cells by affecting bone marrow-derived tumor macrophages, dendritic cells, and myeloid-derived suppressor cells [64].

\section{Agents that block the formation of MDSC Nitro-Bisphosphonates (N-Bisphosphonates)}

$\mathrm{N}$-Bisphosphonates inhibit bone resorbing osteoclasts [65]. They inhibit the enzyme farnesyl-diphosphate (FPP) synthase which is responsible for the generation of geranyl and prenyl compounds that are added to many proteins as post-translational modifications [65]. Treatment with $\mathrm{N}$-Bisphosphonate leads to decreased prenylation of proteins such as matrix metalloproteinase 9 (MMP9). MMP9 may influence MDSC generation/function by cleaving c-kit, which is believed to play a role in MDSC mobilization from the bone marrow niche [66]. MMP9 has also been found to mobilize VEGF thereby making it available to bind to its receptor (VEGFR) on MDSC [23]. N-bisphosphonate treatment of transgenic BALBneuT mice (expressing an activated rat c-erbB-2/neu transgene) that develop metastatic mammary carcinomas resulted in lower levels of MDSC and lower tumor burden compared to untreated control animals. Likewise, use of zoledronic acid with a plasmid DNA vaccine encoding rat $\mathrm{p} 185 / \mathrm{Her}-2$ resulted in delayed tumor growth and the increased induction of anti-p185 /Her-2 antibodies as compared to controls [23]. Porembka et $a l$. studied the effects of the bisphosphonate zoledronic acid on mice inoculated with the pancreatic cancer cell line Panc02. Animals treated with zoledronic acid demonstrated less intra-tumoral MDSC accumulation, and this was associated with delayed tumor growth rate, prolonged median survival, and increased recruitment of $\mathrm{T}$ cells to the tumor. Zoledronic acid treated mice also had increased levels of IFN $\gamma$ and decreased levels of IL-10 within the tumors [67]. Wesolowski and colleagues are presently studying the effects of zoledronic acid on MDSC levels in patients with estrogen receptor positive breast cancer who are receiving endocrine therapy.

\section{Modulators of cell signaling}

Tyrosine kinase signaling has been implicated in the stimulation of early myeloid cell differentiation into MDSC. Constitutive activation of STAT3 in MDSC upregulates anti-apoptotic, pro-proliferative, and proangiogenic genes $[1,68]$. Inhibitors of STAT3 activation such as peptidomimetics, small molecule inhibitors and platinum agents have been employed against MDSC [69]. Derivatives of curcurmin, have been synthesized and have been shown to inhibit STAT3 phosphorylation and subsequent activation [70,71]. Administration of Cucurbitacin B (CuB), a selective inhibitor of the JAK2/
STAT3 pathway, to patients with advanced lung cancers decreased peripheral blood levels of Lin $^{-} \mathrm{HLA}_{-} \mathrm{DR}^{-} \mathrm{CD} 33^{+}$ immature myeloid cells and increased peripheral blood levels of $\mathrm{Lin}^{-} \mathrm{HLA}-\mathrm{DR}^{+} \mathrm{CD} 33^{+}$mature myeloid cells compared with baseline levels. In vitro experiments demonstrated that $\mathrm{CuB}$ induced differentiation of $\mathrm{DC}$ and increased the sensitivity of the tumor cells to p53-specific CTL cells [72].

Sunitinib is a multi-kinase inhibitor that has multiple targets including VEGFR and c-kit. Treatment with sunitinib led to a $50 \%$ reduction in the peripheral blood levels of MDSC in renal cell cancer patients. The decline was associated with improved Th1 lymphocyte function and decreased numbers of Tregs [9]. In contrast, a phase I clinical trial of a VEGF trap demonstrated no effect on peripheral blood levels of MDSC [73]. Similarly, antiVEGF antibody use in patients with renal cell carcinoma did not appear to reduce the levels of peripheral blood MDSC but did increase the levels of mature DCs [74]. This is a surprising finding, given that high levels of VEGF have been associated with the accumulation of immature myeloid DC in cancer patients [1]. However, the discrepancy between pre-clinical and early clinical research can be explained by the heterogeneous patient population participating in the latter, often with various end-stage and treatment refractory malignancies. In addition, these early phase clinical studies are often not powered to provide definitive conclusions based on correlative markers, as they are designed mainly to provide data on the safety of a study drug. This can make interpretation of such results difficult. Additional clinical research utilizing more homogeneous patient populations is warranted.

\section{Agents that decrease MDSC levels}

Some cytotoxic agents have been found to cause MDSC depletion through as yet incompletely understood mechanisms. Gemcitabine treatment of tumor-bearing mice reduced the number of splenic and tumor $\mathrm{Gr} 1^{+} / \mathrm{CD} 11 \mathrm{~b}^{+}$ MDSC without affecting the numbers of $\mathrm{CD}^{+}$or $\mathrm{CD}^{+}$ $\mathrm{T}$ cells or NK cells [75]. Le at al. showed that weekly gemcitabine treatments reduced tumor size and levels of splenic MDSCs in mice bearing 4T1 tumors [76]. Gemcitabine treatment of mice bearing established Panc02 pancreatic adenocarcinomas prior to administration of a modified Vaccinia Ankara (MVA) based viral vaccine against the murine survivin protein led to the greatest reduction in tumor volume compared to controls [15]. Inhibition of MDSC accumulation with gemcitabine also enhanced the activity of a Her-2/neu adenoviral vector vaccine [21]. Other cytotoxic agents may also inhibit MDSC. Cisplatin treatment of C57BL/6 mice bearing $\mathrm{TC}-1$ lung carcinomas resulted in reduced numbers of MDSC and Tregs compared to untreated 
animals [22]. 5-Fluorouracil (5-FU) treatment of EL-7 thymoma-bearing $\mathrm{C} 57 \mathrm{BL} / 6$ mice has been found to lead to a reduction in splenic and tumor MDSC. This agent had no significant effect on other immune cells (T, DC, NK, NKT cells) except for an increase in the number of B cells [77]. Paclitaxel, an agent that inhibits disassembly of microtubules, may down-regulate the function of MDSC by causing them to differentiate into mature DC [78].

Other strategies for depletion of MDSCs are emerging. One approach involves the use of the heat shock protein 90 (HSP90) inhibitor, 17-DMAG (17-Dimethylaminoethylamino17-demethoxygeldanamycin). When cells are treated with 17-DMAG, EphA2 (HSP90 client protein) is degraded by the proteasome. Tumor cells can then be recognized by Type-1 anti-EphA2 CD8+ cells. When an antibody to EphA2 and an inhibitor to HSP90 are combined in a sarcoma murine model, mice are rendered free of sarcoma and this has been associated with reduced numbers of MDSC [79]. Combination therapy with 17-DMAG apparently reconditions the tumor microenvironment improving the recruitment of anti-tumor $\mathrm{T}$ cells. It has been hypothesized that FAS ligand (FASL) positive T cells might be important in the regulation of MDSC survival. FAS(+) MDSCs were shown to be susceptible to FAS-mediated killing in vitro[80]. In addition, a recent study showed that blocking IL-6R, a key receptor to a cytokine that is associated with suppression of the cytotoxic immune response, may also lead to decreases in accumulation of monocytic and granulocytic MDSC, reduction in tumor growth and improvement in T-cell function in squamous cell carcinoma of the skin (CMC-1 cells) bearing tumor bearing mice (all compared to control tumor bearing animals). Gemcitabine used alongside with a monoclonal antibody against IL-6R led to greater downmodulation of MDSC compared to use of the monoclonal antibody alone [81].

Nakashima et al. depleted MDSC via the use of IL-13 linked to Pseudomonas exotoxin (IL-13-PE) in combination with a DNA vaccine against IL-13R $\alpha 2$. They tested this combination therapy on C57BL/6 and BALB/c mice bearing established MCA307 sarcoma tumors and 4T1 breast carcinoma tumors that both naturally express the IL-13R $\alpha$. Mice that were treated with IL-13-PE followed by injection of the IL-13R $\alpha 2$ DNA vaccine had a 5 -fold greater decrease in tumor growth compared to the animals that received the vaccine alone. Treatment of mice with IL-13-PE and the IL-13R $\alpha 2$ vaccine resulted in depletion of MDSC, increased numbers of $\mathrm{CD}^{+} \mathrm{T}$ cells and the release of IFNY [19]. IL-13 may be playing crucial role in the MDSC-mediated $\mathrm{T}$ cell interaction and increased levels of IL-13 are associated with increased levels of MDSC [10]. Other strategies to deplete MDSC in murine experiments involved the use of antibodies against the Gr1 antigen. Treatment of tumor bearing mice with anti-Gr1+ antibodies resulted in retardation of tumor growth [1,7]. However, Gr1 is a general granulocyte marker and may also deplete neutrophils making this MDSC depleting strategy controversial. It is also important to note that $\mathrm{Gr} 1$ antigen is not present on human MDSC. However, these experiments suggest that depletion of MDSC could be an effective adjunct to immunotherapies in the clinical setting.

\section{Conclusion}

Pre-clinical evidence suggests that cancer vaccines are more effective in tumor bearing mice that have been depleted of MDSC $[14,17,18,23]$. The overall mechanism of cancer mediated expansion of MDSC and the resultant immune suppression is expected to be similar between humans and mice making the results of murine experiments useful in developing new anti-MDSC agents and testing them in clinical trials. There is wide range of potential therapeutic targets that are involved in MDSC production and their immunosuppressive function. MDSC may be inhibited via the use of phosphodiesterase inhibitors, nitroaspirins, synthetic triterpenoids, COX2 inhibitors, ARG1 inhibitors, anti-glycan antibodies, CSF-1R, IL-17 inhibitors and histamine based approaches. MDSC may be differentiated by using ATRA, vitamins A or D3 or IL-12. Agents that block the formation of MDSC include N-Bisphosphonates, modulators of tyrosine kinases, and STAT3 inhibitors. Agents that decrease levels of MDSC include gemcitabine, HSP90 inhibitors, and paclitaxel. Some compounds, such as ATRA, PDE5 inhibitors, nitro-aspirins (e.x. NCX 4016), or tyrosine kinase inhibitors are already in clinical trials testing their ability to inhibit MDSC and enhance anti-tumor immunity in humans. Others such as anti-histamines, anti-glycan inhibitors, CpG, IL-12, IL-13-PE or HSP 90 inhibitors are still undergoing testing as MDSC inhibitors in pre-clinical models. Compounds already FDA approved (e.g. ATRA, PDE5 inhibitors, COX-2 inhibitors or bisphosphonates) will likely be the first to enter late phase clinical trials to test their ability to suppress MDSC and improve the efficacy of immune modulating therapies (immune checkpoint inhibitors or cancer vaccines). Further research is needed to identify the most promising compounds for clinical development.

Abbreviations

5-FU: 5-Fluorouracil; AOM: Azoxymethane; ADC: Antibody drug conjugate; ARG: Arginase; ATRA: All-trans retinoic acid; CAR: Chimeric antigen receptor: CCL: Chemokine CC motif Ligand; CD: Cluster of differentiation; CDDO-Me: Bardoxolone methyl; CSF-1R: Colony stimulating factor receptor 1; CGMP: Cyclic guanosine monophosphate; CpG: Unmethylated deoxycytosine-deoxyguanine dinucleotide (CpG) motifs; CpG ODN: Oligodexynucleotides; CTL: Cytotoxic T lymphocytes; CXCL: CXC 
Chemokine Ligand; COX2: Cyclooxygenase 2; CuB: Cucurbitacin B; DC: Dendritic cells; DSS: Dextran sodium sulfate; DNA: Deoxyribonucleic acid; EphA2: Ephrin type-A receptor 2; FasL: Fas ligand; FoxP3: Forkhead box P3; FPP: Farnesyl-diphosphate; G-CSF: Granulocyte colony stimulating factor; GMCSF: Granulocyte monocyte colony stimulating factor; gp70env: Envelope glycoprotein gp70; Gr1: Granulocyte differentiation antigen 1; H2 blockers: Histamine H2 receptor blockers; Her-2/neu: Human epiderrmal growth factor receptor 2; HLA: Human leukocyte antigen; HPV: Human papilloma virus; HSP90: Heat shock protein 90; IDO: Indoleamine 2,3Dioxygenase; IFN: Interferon; IFNYR: Interferon gamma receptor; IL: Interleukin; IL-13-PE: IL-13 Linked to pseudomonas exotoxin; IL4Ra: Interleukin 4 Receptor a chain; JAK2: Janus-Activated Kinase-2; Lin: Lineage marker; L-NAME: N(G)-Nitro-L-Arginine Methyl Ester; MDSC: Myeloid derived suppressor cell(s); mRNA: messenger ribonucleic acid; MMP9: Metalloproteinase 9; MVA: Modified vaccinia ankara:

NADPH: Nicotinamide adenine dinucleotide phosphate (reduced); NF-kB: Nuclear Factor kappa-light-chain-enhancer of activated B cells; NK: Natural Killer cells; NKT: Natural killer T cells; NO-aspirin: Nitro-aspirin; NOHA: N-hydroxy-L-Arginine; NOS: Nitric oxide synthase; NQO1: Quinone oxidoreductase 1; NRF2: Nuclear factor-erythroid 2-Related Factor 2; PBMC: Peripheral blood mononuclear cells; PGE: Prostaglandin E; PGE-5: Phosphodiesterase-5; RAGE: Receptor for advanced Glycation End products; RAR: Retinoid-activated transcriptional regulators; ROS: Reactive oxygen species; STAT: Signal transducer and activator of transcription; Th1: Type 1 T-helper cells; Th2: Type 2 T-helper cells; TLR: Tall-Like Receptor; TNF: Tumor necrosis factor; Tregs: T regulatory cells; TRAMP: Transgenic adenocarcinoma of the mouse prostate; VEGF: Vascular endothelial growth factor; VEGFR-2: Vascular endothelial growth factor receptor 2.

\section{Competing interests}

All authors declare that they have no competing interests.

\section{Authors' contributions}

RW performed the literature search; drafted and edited all versions of the manuscript; incorporated all edits from JM and WC. JM performed literature search, made substantial contributions to all drafts of the manuscripts both in terms of content and organization. Supervised preparation of the manuscript; contributed ideas and publications to be used in drafting the manuscript; read and edited all drafts of the manuscript. All authors read and approved the final manuscript.

\section{Authors' information}

RW is an Assistant Professor in Department of Internal Medicine at Ohio State University on a tenure track. Dr. Wesolowski is a board certified academic medical oncologist involved in translational and clinical research and treatment of breast cancer. He currently collaborates with Dr. William Carson's laboratory. His research interests are in tumor immunology, early phase clinical trials and prognostic and predictive value of Myeloid Derived Suppressor Cells (MDSC). $\mathrm{JM}$ is a physician scientist, is a U.S. Board Certified Internist who has just completed a clinical Medical Oncology training program. Currently, he is working in the laboratory of Dr. William Carson as a postdoctoral fellow. To date, he has had experience both in pre-clinical and clinical development of experimental therapeutics including a published patent. He has expertise in biochemistry, protein NMR spectroscopy, and fluorescence spectroscopy. He has joined Dr. Carson's laboratory to gain experience in immunology and animal tumor models. WC is a Professor of Surgery and Medical Microbiology and Immunology. Dr. Carson is also an associate director of clinical research at the Ohio State University Comprehensive Cancer Center and a co-leader of the institution's Immunology Program. He is co-Investigator on a Project Program Grant in Innate Immunity. Dr. Carson chairs the Institutional Review Board at the Ohio State University, and is the Institutional principal investigator for National Comprehensive Cancer Network. He has a laboratory and focuses on work related to exploring interactions of immune system and malignancies. He also specifically investigates immune function of MDSC. His work includes testing MDSC inhibitors and studying pre-clinical models of MDSC inhibition that would facilitate the development of early clinical trials with MDSC modulating agents. Robert Wesolowski and Joseph Markowitz are co-first authors.

\section{Acknowledgements}

We would like to acknowledge UL1TR000090 from the National Center For Advancing Translational Sciences (to R. Wesolowski), T32CA090223 (to J. Markowitz) and P01 CA95426-08 (to W.E. Carson).

\section{Author details}

'Division of Medical Oncology, B401 Starling Loving Hall, W10th Avenue, Columbus, OH 43210, USA. ${ }^{2}$ Division of Medical Oncology, 406C Starling Loving Hall 320 W 10th Ave, Columbus, OH 43210, USA. ${ }^{3}$ The Ohio State University Comprehensie Cancer Center, N911 Doan Hall, 410 West 10th Avenue, Columbus, $\mathrm{OH}$ 43210, USA.

Received: 28 January 2013 Accepted: 14 June 2013

Published: 15 July 2013

\section{References}

1. Gabrilovich DI, Nagaraj S: Myeloid-derived suppressor cells as regulators of the immune system. Nat Rev Immunol 2009, 9:162-174.

2. Greten TF, Manns MP, Korangy F: Myeloid derived suppressor cells in human diseases. Int Immunopharmacol 2011, 11:802-807.

3. Filipazzi P, Huber V, Rivoltini L: Phenotype, function and clinical implications of myeloid-derived suppressor cells in cancer patients. Cancer Immunol Immunother 2012, 61:255-263.

4. Mundy-Bosse BL, Young GS, Bauer T, Binkley E, Bloomston M, Bill MA, BekaiiSaab T, Carson WE 3rd, Lesinski GB: Distinct myeloid suppressor cell subsets correlate with plasma IL- 6 and IL-10 and reduced interferonalpha signaling in $\mathrm{CD}^{+} \mathrm{T}$ cells from patients with $\mathrm{Gl}$ malignancy. Cancer Immunol Immunother 2011, 60:1269-1279.

5. Movahedi K, Guilliams M, Van den Bossche J, Van den Bergh R, Gysemans C, Beschin A, De Baetselier P, Van Ginderachter JA: Identification of discrete tumor-induced myeloid-derived suppressor cell subpopulations with distinct T cell-suppressive activity. Blood 2008, 111:4233-4244.

6. Sawanobori Y, Ueha S, Kurachi M, Shimaoka T, Talmadge JE, Abe J, Shono Y, Kitabatake M, Kakimi K, Mukaida N, Matsushima K: Chemokine-mediated rapid turnover of myeloid-derived suppressor cells in tumor-bearing mice. Blood 2008, 111:5457-5466.

7. Gabrilovich DI, Ostrand-Rosenberg S, Bronte V: Coordinated regulation of myeloid cells by tumours. Nat Rev Immunol 2012, 12:253-268.

8. Almand B, Clark Jl, Nikitina E, van Beynen J, English NR, Knight SC, Carbone DP, Gabrilovich DI: Increased production of immature myeloid cells in cancer patients: a mechanism of immunosuppression in cancer. $J$ Immunol 2001, 166:678-689.

9. Ko JS, Zea AH, Rini BI, Ireland JL, Elson P, Cohen P, Golshayan A, Rayman PA, Wood L, Garcia J, Dreicer R, Bukowski R, Finke JH: Sunitinib mediates reversal of myeloid-derived suppressor cell accumulation in renal cell carcinoma patients. Clin Cancer Res 2009, 15:2148-2157.

10. Gabitass RF, Annels NE, Stocken DD, Pandha HA, Middleton GW: Elevated myeloid-derived suppressor cells in pancreatic, esophageal and gastric cancer are an independent prognostic factor and are associated with significant elevation of the Th2 cytokine interleukin-13. Cancer Immunol Immunother 2011, 60:1419-1430.

11. Montero AJ, Diaz-Montero CM, Kyriakopoulos CE, Bronte V, Mandruzzato S: Myeloid-derived suppressor cells in cancer patients: a clinical perspective. J Immunother 2012, 35:107-115.

12. Malmberg KJ: Effective immunotherapy against cancer: a question of overcoming immune suppression and immune escape. Cancer Immunol Immunother 2004, 53:879-892.

13. Mundy-Bosse BL, Lesinski GB, Jaime-Ramirez AC, Benninger K, Khan M, Kuppusamy P, Guenterberg K, Kondadasula SV, Chaudhury AR, La Perle KM, Kreiner M, Young G, Guttridge DC, Carson WE 3rd: Myeloid-derived suppressor cell inhibition of the IFN response in tumor-bearing mice. Cancer Res 2011, 71:5101-5110.

14. Kusmartsev S, Cheng F, Yu B, Nefedova Y, Sotomayor E, Lush R, Gabrilovich D: All-trans-retinoic acid eliminates immature myeloid cells from tumor bearing mice and improves the effect of vaccination. Cancer Res 2003, 63:4441-4449.

15. Ishizaki H, Manuel ER, Song GY, Srivastava T, Sun S, Diamond DJ, Ellenhorn: Modified vaccinia Ankara expressing survivin combined with gemcitabine generates specific antitumor effects in a murine pancreatic carcinoma model. Cancer Immunol Immunother 2011, 60:99-109.

16. Weiss T, Vitacolonna M, Zöller M: The efficacy of an IL-1alpha vaccine depends on IL-1RI availability and concomitant myeloid-derived suppressor cell reduction. J Immunother 2009, 32:552-564.

17. De Santo C, Serafini P, Marigo I, Dolcetti L, Bolla M, Del Soldato P, Melani C, Guiducci C, Colombo MP, lezzi M, Musiani P, Zanovello P, Bronte V: Nitroaspirin corrects immune dysfunction in tumor-bearing hosts and 
promotes tumor eradication by cancer vaccination. Proc Natl Acad Sci USA 2005, 102:4185-4190.

18. Nagaraj S, Youn Jl, Weber H, Iclozan C, Lu L, Cotter MJ, Meyer C, Becerra CR, Fishman M, Antonia S, Sporn MB, Liby KT, Rawal B, Lee JH, Gabrilovich DI: Anti-inflammatory triterpenoid blocks immune suppressive function of MDSCs and improves immune response in cancer. Clin Cancer Res 2010, 16:1812-1823.

19. Nakashima H, Terabe M, Berzofsky JA, Husain SR, Puri RK: A novel combination immunotherapy for cancer by IL-13Ra2-targeted DNA vaccine and immunotoxin in murine tumor models. J Immunol 2011 187:4935-4946.

20. Bose A, Taylor JL, Alber S, Watkins SC, Garcia JA, Rini BI, Ko JS, Cohen PA Finke JH, Storkus WJ: Sunitinib facilitates the activation and recruitment of therapeutic anti-tumor immunity in concert with specific vaccination. Int J Cancer 2011, 129:2158-2170.

21. Ko HJ, Kim YJ, Kim YS, Chang WS, Ko SY, Chang SY, Sakaguchi S, Kang CY: A combination of chemoimmunotherapies can efficiently break selftolerance and induce antitumor immunity in a tolerogenic murine tumor model. Cancer Res 2007, 67:7477-7486.

22. Tseng CW, Hung CF, Alvarez RD, Trimble C, Huh WK, Kim D, Chuang CM, Lin CT, Tsai YC, He L, Monie A, Wu TC: Pretreatment with cisplatin enhances E7-specific CD8+ T-Cell-mediated antitumor immunity induced by DNA vaccination. Clin Cancer Res 2008, 14:3185-3192.

23. Melani C, Sangaletti S, Barazzetta FM, Werb Z, Colombo MP: Aminobiphosphonate-mediated MMP-9 inhibition breaks the tumor-bone marrow axis responsible for myeloid-derived suppressor cell expansion and macrophage infiltration in tumor stroma. Cancer Res 2007, 67:11438-11446.

24. Serafini P, Meckel K, Kelso M, Noonan K, Califano J, Koch W, Dolcetti L, Bronte $V$, Borrello I: Phosphodiesterase-5 inhibition augments endogenous antitumor immunity by reducing myeloid-derived suppressor cell function. J Exp Med 2006, 203:2691-2702.

25. Rodriguez PC, Zea AH, Culotta KS, Zabaleta J, Ochoa JB, Ochoa AC Regulation of $\mathrm{T}$ cell receptor CD3zeta chain expression by L-arginine. J Biol Chem 2002, 277:21123-21129.

26. Schreiber RD, Old LJ, Smyth MJ: Cancer immunoediting: integrating immunity's roles in cancer suppression and promotion. Science 2011. 331:1565-1570.

27. Sinha P, Parker KH, Horn L, Ostrand-Rosenberg S: Tumor-induced myeloidderived suppressor cell function is independent of IFNy and IL-4Ra. Eur J Immunol 2012, 42:2052-2059.

28. Nagaraj S, Schrum AG, Cho HI, Celis E, Gabrilovich DI: Mechanism of T cell tolerance induced by myeloid-derived suppressor cells. J Immunol 2010, 184:3106-3116

29. Molon B, Ugel S, Del Pozzo F, Soldani C, Zilio S, Avella D, De Palma A, Mauri P, Monegal A, Rescigno M, Savino B, Colombo P, Jonjic N, Pecanic S, Lazzarato L, Fruttero R, Gasco A, Bronte V, Viola A: Chemokine nitration prevents intratumoral infiltration of antigen-specific T cells. J Exp Med 2011, 208:1949-1962.

30. Fiorucci S, Santucci L, Cirino G, Mencarelli A, Familiari L, Soldato PD, Morelli A IL-1 beta converting enzyme is a target for nitric oxide-releasing aspirin: new insights in the antiinflammatory mechanism of nitric oxide-releasing nonsteroidal antiinflammatory drugs. J Immunol 2000, 165:5245-5254.

31. Thimmulappa RK, Fuchs RJ, Malhotra D, Scollick C, Traore K, Bream JH, Trush MA, Liby KT, Sporn MB, Kensler TW, Biswal S: Preclinical evaluation of targeting the Nrf2 pathway by triterpenoids (CDDO-Im and CDDO-Me) for protection from LPS-induced inflammatory response and reactive oxygen species in human peripheral blood mononuclear cells and neutrophils. Antioxid Redox Signal 2007, 9:1963-1970.

32. Ahmad R, Raina D, Meyer C, Kufe D: Triterpenoid CDDO-methyl ester inhibits the Janus-activated kinase-1 (JAK1)- > signal transducer and activator of transcription-3 (STAT3) pathway by direct inhibition of JAK1 and STAT3. Cancer Res 2008, 68:2920-2926.

33. Sinha P, Clements VK, Fulton AM, Ostrand-Rosenberg S: Prostaglandin E2 promotes tumor progression by inducing myeloid-derived suppressor cells. Cancer Res 2007, 67:4507-4513.

34. Rodriguez PC, Hernandez CP, Quiceno D, Dubinett SM, Zabaleta J, Ochoa JB, Gilbert J, Ochoa AC: Arginase I in myeloid suppressor cells is induced by COX-2 in lung carcinoma. J Exp Med 2005, 202:931-939.

35. Talmadge JE, Hood KC, Zobel LC, Shafer LR, Coles M, Toth $B$ : Chemoprevention by cyclooxygenase- 2 inhibition reduces immature myeloid suppressor cell expansion. Int Immunopharmacol 2007, 7:140-151.
36. Veltman JD, Lambers ME, van Nimwegen M, Hendriks RW, Hoogsteden HC, Aerts JG, Hegmans JP: COX-2 inhibition improves immunotherapy and is associated with decreased numbers of myeloid-derived suppressor cells in mesothelioma. Celecoxib influences MDSC function. BMC Cancer 2010, 10:464.

37. Stuehr DJ, Kwon NS, Nathan CF, Griffith OW, Feldman PL, Wiseman J: N omega-hydroxy-l-arginine is an intermediate in the biosynthesis of nitric oxide from I-arginine. J Biol Chem 1991, 266:6259-6263.

38. Serafini P, Mgebroff S, Noonan K, Borrello I: Myeloid-derived suppressor cells promote cross-tolerance in B-cell lymphoma by expanding regulatory T cells. Cancer Res 2008, 68:5439-5449.

39. Reisser D, Onier-Cherix N, Jeannin JF: Arginase activity is inhibited by LNAME, both in vitro and in vivo. J Enzyme Inhib Med Chem 2002, 17:267-270.

40. Nanni S, Benvenuti V, Grasselli A, Priolo C, Aiello A, Mattiussi S, Colussi C, Lirangi V, Illi B, D'Eletto M, Cianciulli AM, Gallucci M, De Carli P, Sentinelli S, Mottolese M, Carlini P, Strigari L, Finn S, Mueller E, Arcangeli G, Gaetano C, Capogrossi MC, Donnorso RP, Bacchetti S, Sacchi A, Pontecorvi A, Loda M, Farsetti A: Endothelial NOS, estrogen receptor beta, and HIFs cooperate in the activation of a prognostic transcriptional pattern in aggressive human prostate cancer. J Clin Invest 2009, 119:1093-1108.

41. Capuano G, Rigamonti N, Grioni M, Freschi M, Bellone M: Modulators of arginine metabolism support cancer immunosurveillance. BMC Immunol 2009, 10:1.

42. Rigamonti N, Capuano G, Ricupito A, Jachetti E, Grioni M, Generoso L, Freschi M, Bellone M: Modulators of arginine metabolism do not impact on peripheral T-cell tolerance and disease progression in a model of spontaneous prostate cancer. Clin Cancer Res 2011, 17:1012-1023.

43. Cheng P, Corzo CA, Luetteke N, Yu B, Nagaraj S, Bui MM, Ortiz M, Nacken W, Sorg C, Vogl T, Roth J, Gabrilovich DI: Inhibition of dendritic cell differentiation and accumulation of myeloid-derived suppressor cells in cancer is regulated by S100A9 protein. J Exp Med 2008, 205:2235-2249.

44. Turovskaya O, Foell D, Sinha P, Vogl T, Newlin R, Nayak J, Nguyen M, Olsson A, Nawroth PP, Bierhaus A, Varki N, Kronenberg M, Freeze HH, Srikrishna G: RAGE, carboxylated glycans and S100A8/A9 play essential roles in colitisassociated carcinogenesis. Carcinogenesis 2008, 29:2035-2043.

45. Sinha P, Okoro C, Foell D, Freeze HH, Ostrand-Rosenberg S, Srikrishna G: Proinflammatory $\mathrm{S} 100$ proteins regulate the accumulation of myeloidderived suppressor cells. J Immunol 2008, 181:4666-4675.

46. Priceman SJ, Sung JL, Shaposhnik Z, Burton JB, Torres-Collado AX, Moughon DL, Johnson M, Lusis AJ, Cohen DA, Iruela-Arispe ML, Wu L: Targeting distinct tumor-infiltrating myeloid cells by inhibiting CSF-1 receptor: combating tumor evasion of antiangiogenic therapy. Blood 2010, 115:1461-1471.

47. Xu J, Escamilla J, Mok S, David J, Priceman S, West B, Bollag G, McBride W, Wu L: CSF1R signaling blockade stanches tumor-infiltrating myeloid cells and improves the efficacy of radiotherapy in prostate cancer. Cancer Res 2013, 73:2782-2794

48. Mor S, Nagler A, Barak V, Handzel ZT, Geller-Bernstein C, Fabian I: Histamine enhances granulocyte-macrophage colony-stimulating factor and interleukin- 6 production by human peripheral blood mononuclear cells. J Leukoc Biol 1995, 58:445-450

49. Yang XD, Ai W, Asfaha S, Bhagat G, Friedman RA, Jin G, Park H, Shykind B, Diacovo TG, Falus A, Wang TC: Histamine deficiency promotes inflammation-associated carcinogenesis through reduced myeloid maturation and accumulation of CD11b + Ly6G + immature myeloid cells. Nat Med 2011, 17:87-95.

50. Thoren FB, Aurelius J, Martner A: Antitumor properties of histamine in vivo. Nat Med 2011, 17:537.

51. Zheng Y, Xu M, Li X, Jia J, Fan K, Lai G: Cimetidine suppresses lung tumor growth in mice through proapoptosis of myeloid-derived suppressor cells. Mol Immunol 2012, 54:74-83.

52. He D, Li H, Yusuf N, Elmets CA, Li J, Mountz JD, Xu H: IL-17 promotes tumor development through the induction of tumor promoting microenvironments at tumor sites and myeloid-derived suppressor cells. $\mathrm{J}$ Immunol 2010, 184:2281-2288.

53. Bastien J, Rochette-Egly C: Nuclear retinoid receptors and the transcription of retinoid-target genes. Gene 2004, 328:1-16.

54. Hengesbach LM, Hoag KA: Physiological concentrations of retinoic acid favor myeloid dendritic cell development over granulocyte development in cultures of bone marrow cells from mice. J Nutr 2004, 134:2653-2659. 
55. Kusmartsev S, Su Z, Heiser A, Dannull J, Eruslanov E, Kübler H, Yancey D, Dahm P, Vieweg J: Reversal of myeloid cell-mediated immunosuppression in patients with metastatic renal cell carcinoma. Clin Cancer Res 2008, 14:8270-8278.

56. Mirza N, Fishman M, Fricke I, Dunn M, Neuger AM, Frost TJ, Lush RM, Antonia S, Gabrilovich DI: All-trans-retinoic acid improves differentiation of myeloid cells and immune response in cancer patients. Cancer Res 2006, 66:9299-9307.

57. Wiers KM, Lathers DM, Wright MA, Young MR: Vitamin D3 treatment to diminish the levels of immune suppressive CD34 cells increases the effectiveness of adoptive immunotherapy. J Immunother 2000, 23:115-124.

58. Lathers DM, Clark Jl, Achille NJ, Young MR: Phase 1B study to improve immune responses in head and neck cancer patients using escalating doses of 25-hydroxyvitamin D3. Cancer Immunol Immunother 2004, 53:422-430.

59. Roda JM, Parihar R, Carson WE 3rd: CpG-containing oligodeoxynucleotides act through TLR9 to enhance the NK cell cytokine response to antibodycoated tumor cells. J Immunol 2005, 175:1619-1627.

60. Zoglmeier C, Bauer H, Nörenberg D, Wedekind G, Bittner P, Sandholzer N, Rapp M, Anz D, Endres S, Bourquin C: CpG blocks immunosuppression by myeloid-derived suppressor cells in tumor-bearing mice. Clin Cancer Res 2011, 17:1765-1775

61. Sinha P, Clements VK, Bunt SK, Albelda SM, Ostrand-Rosenberg S: Cross-talk between myeloid-derived suppressor cells and macrophages subverts tumor immunity toward a type 2 response. J Immunol 2007, 179:977-983.

62. Steding CE, Wu ST, Zhang Y, Jeng MH, Elzey BD, Kao C: The role of interleukin-12 on modulating myeloid-derived suppressor cells, increasing overall survival and reducing metastasis. Immunology 2011, 133:221-238.

63. Chinnasamy D, Yu Z, Kerkar SP, Zhang L, Morgan RA, Restifo NP, Rosenberg $\mathrm{SA}$ : Local delivery of interleukin-12 using $T$ cells targeting VEGF receptor2 eradicates multiple vascularized tumors in mice. Clin Cancer Res 2012, 18:1672-1683

64. Kerkar SP, Goldszmid RS, Muranski P, Chinnasamy D, Yu Z, Reger RN, Leonardi AJ, Morgan RA, Wang E, Marincola FM, Trinchieri G, Rosenberg SA, Restifo NP: IL-12 triggers a programmatic change in dysfunctional myeloidderived cells within mouse tumors. J Clin Invest 2011, 121:4746-4757.

65. Rodan GA, Fleisch HA: Bisphosphonates: mechanisms of action. J Clin Invest 1996, 97:2692-2696.

66. Heissig B, Hattori K, Dias S, Friedrich M, Ferris B, Hackett NR, Crystal RG, Besmer P, Lyden D, Moore MA, Werb Z, Rafii S: Recruitment of stem and progenitor cells from the bone marrow niche requires MMP-9 mediated release of kit-ligand. Cell 2002, 109:625-637.

67. Porembka MR, Mitchem JB, Belt BA, Hsieh CS, Lee HM, Herndon J, Gillanders WE, Linehan DC, Goedegebuure P: Pancreatic adenocarcinoma induces bone marrow mobilization of myeloid-derived suppressor cells which promote primary tumor growth. Cancer Immunol Immunother 2012 , 61:1373-1385

68. Ugel S, Delpozzo F, Desantis G, Papalini F, Simonato F, Sonda N, Zilio S, Bronte V: Therapeutic targeting of myeloid-derived suppressor cells. Curr Opin Pharmacol 2009, 9:470-481.

69. Sansone P, Bromberg J: Targeting the Interleukin-6/Jak/Stat pathway in human malignancies. J Clin Oncol 2012, 30:1005-1014

70. Lin L, Deangelis S, Foust E, Fuchs J, Li C, Li PK, Schwartz EB, Lesinski GB, Benson D, Lü J, Hoyt D, Lin J: A novel small molecule inhibits STAT3 phosphorylation and DNA binding activity and exhibits potent growth suppressive activity in human cancer cells. Mol Cancer 2010, 9:217.

71. Bill MA, Fuchs JR, Li C, Yui J, Bakan C, Benson DM Jr, Schwartz EB, Abdelhamid D, Lin J, Hoyt DG, Fossey SL, Young GS, Carson WE 3rd, Li PK, Lesinski GB: The small molecule curcumin analog FLLL32 induces apoptosis in melanoma cells via STAT3 inhibition and retains the cellular response to cytokines with anti-tumor activity. Mol Cancer 2010, 9:165.

72. Lu $P, Y u B, X u J$ : Cucurbitacin B regulates immature myeloid cell differentiation and enhances antitumor immunity in patients with lung cancer. Cancer Biother Radiopharm 2012, 27:495-503.

73. Fricke I, Mirza N, Dupont J, Lockhart C, Jackson A, Lee JH, Sosman JA, Gabrilovich DI: Treatment of cancer patients with VEGF-Trap overcomes defects in DC differentiation but is insufficient to improve antigenspecific immune responses. Clin Cancer Res 2007, 13:4840-4848.

74. Rodriguez PC, Ernstoff MS, Hernandez C, Atkins M, Zabaleta J, Sierra R, Ochoa AC: Arginase I-producing myeloid-derived suppressor cells in renal cell carcinoma are a subpopulation of activated granulocytes. Cancer Res 2009, 69:1553-1560.

75. Suzuki E, Kapoor V, Jassar AS, Kaiser LR, Albelda SM: Gemcitabine selectively eliminates splenic Gr-1+/CD11b + myeloid suppressor cells in tumor-bearing animals and enhances antitumor immune activity. Clin Cancer Res 2005, 11:6713-6721.

76. Le HK, Graham L, Cha E, Morales JK, Manjili MH, Bear HD: Gemcitabine directly inhibits myeloid derived suppressor cells in BALB/c mice bearing 4T1 mammary carcinoma and augments expansion of T cells from tumor-bearing mice. Int Immunopharmacol 2009, 9:900-909.

77. Vincent J, Mignot G, Chalmin F, Ladoire S, Bruchard M, Chevriaux A, Martin F, Apetoh L, Rébé C, Ghiringhelli F: 5-Fluorouracil selectively kills tumorassociated myeloid-derived suppressor cells resulting in enhanced T celldependent antitumor immunity. Cancer Res 2010, 70:3052-3061.

78. Naiditch $H$, Shurin MR, Shurin GV: Targeting myeloid regulatory cells in cancer by chemotherapeutic agents. Immunol Res 2011, 50:276-285.

79. Rao A, Taylor JL, Chi-Sabins N, Kawabe M, Gooding WE, Storkus WJ: Combination therapy with HSP90 inhibitor 17-DMAG reconditions the tumor microenvironment to improve recruitment of therapeutic $T$ cells. Cancer Res 2012, 72:3196-3206.

80. Ostrand-Rosenberg S, Sinha P, Chornoguz O, Ecker C: Regulating the suppressors: apoptosis and inflammation govern the survival of tumorinduced myeloid-derived suppressor cells (MDSC). Cancer Immunol Immunother 2012, 61:1319-1325.

81. Sumida K, Wakita D, Narita Y, Masuko K, Terada S, Watanabe K, Satoh T, Kitamura H, Nishimura T: Anti-IL-6 receptor mAb eliminates myeloidderived suppressor cells and inhibits tumor growth by enhancing T-cell responses. Eur J Immunol 2012, 42:2060-2072.

doi:10.1186/2051-1426-1-10

Cite this article as: Wesolowski et al:: Myeloid derived suppressor cells a new therapeutic target in the treatment of cancer. Journal for ImmunoTherapy of Cancer 2013 1:10.

\section{Submit your next manuscript to BioMed Central and take full advantage of:}

- Convenient online submission

- Thorough peer review

- No space constraints or color figure charges

- Immediate publication on acceptance

- Inclusion in PubMed, CAS, Scopus and Google Scholar

- Research which is freely available for redistribution 